University for Business and Technology in Kosovo

UBT Knowledge Center

Nov 1st, 5:45 PM - 6:00 PM

\title{
Illegal Serbian Structures in the Republic of Kosovo Why these structures are illegal and not paralel?
}

\author{
Behar Selimi \\ University for Business and Technology
}

Follow this and additional works at: https://knowledgecenter.ubt-uni.net/conference

Part of the Law Commons

\section{Recommended Citation}

Selimi, Behar, "Illegal Serbian Structures in the Republic of Kosovo Why these structures are illegal and not paralel?" (2013). UBT International Conference. 45.

https://knowledgecenter.ubt-uni.net/conference/2013/all-events/45

This Event is brought to you for free and open access by the Publication and Journals at UBT Knowledge Center. It has been accepted for inclusion in UBT International Conference by an authorized administrator of UBT Knowledge Center. For more information, please contact knowledge.center@ubt-uni.net. 


\title{
Illegal Serbian Structures in the Republic of Kosovo Why these structures are illegal and not paralel?
}

\author{
Behar Selimi \\ University of Business and Technology \\ Pristina, Kosova
}

\begin{abstract}
The phenomenon of parallel structures or "a state within a state" is not new. The occurrence of the creation and operation of parallel institutions representing popular sovereignty is a socio-political phenomenon that accompanies transition societies. Such are considered societies emerging from colonization and those emerging from the process of revolutionary and evolutionary trans formations of the communist system. However not all such structures that considers their activity to be parallel, ar as such. Number of these structures appears to be illegal and their actions are considered to be illegal. With regard to the Serbian illegal structures operating in Republic of Kosovo, the withdrawal forced under NATO intervention of Serb-Yugoslav mechanisms of power from Kosovo in June 1999 marks the end of the war and at the same time the beginning of a new process of peace building. Despite the massive military and police withdrawal, members of the Serbian structures of security continued to reside in predominantly Serb enclaves, most of which began to reorganize, to defend the policy of S. Milosevic, whose regime continued to support the Serb strong line on staying in Kosovo by all means. However, these illegal structures do not represent majority of Serbs living in Kosovo, considering that this majority is incorporated into the constitutional institutions of the Rrepublic of Kosovo.This paper will scrutinize all of the aspects related to the illegal Serbian structures (supported also by the Government of Serbia) by showing why these structures are illegal and not parallel!
\end{abstract}

Keywor ds: Illegal, Paralel, Structures, Security, Institution.

\section{Introduction}

Since the end of the Kosovo war (1999) until today, a multidimensional major problem continues to be the full integration of the Serb minority in the new Kosovar society. While the absolute majority of the community in other municipalities of Kosovo has become part of institutions and new life, the rest in the north of Kosovo continues to resist all efforts, both domestic and international, for their in tegration in the Republic of Kosovo. One of the main obstacles to the realization of the integration process continues to be access to illegal, even criminal, structures subsequently considered to be parallel structures and as such tolerated on the assumption that tolerance and cooperation with them helps keep the peace and stability. It is precisely the origin of these structures and their dilemmas on how to name them will be the topic of this paper. In a summarized way we will try to clarify the misuse by the Serbian Government of the ambiguity of international documents on and related to Kosovo, which aims at supporting and political and diplomatic instrumentalization of these structures. The Kumanovo Technical Agreement between the International Security Force (KFOR) on the one hand and the Government of the Federal Republic of Yugoslavia and the Republic of Serbia, on the other, marks the beginning of the withdrawal of Serb apparatus of force from Kosovo. A day later, the UN Security Council adopted Resolution 1244, which a posteriori justified military arrangements of administration over Kosovo, determining and authorizing civilian components of UN international civilian mission. In both these documents, as well as in other proceeding documents, there was a continued and frequently repeated commitment and confirmation of the international community to respect the sovereignty and territorial integrity of Yugoslavia over Kosovo, as well as the assurance for a political solution to the Kosovo crisis in the context of a "substantial autonomy and significant self-governance". It was precisely the hope of official Belgrade and the Kosovo Serb community conviction that the Serb administration could return in one form or another within an eventual state rearrangement that was the reason for the preservation of different sectors of civil structures, including security sectors, although 
the latter are without power and still operating without visible presence. Of course, after the establishment of the interim international administration in Kosovo these structures were reorganized according to the requirements and needs of the Serbian policy, which continued to be considered a legitimate policy for the Kosovo Serbs. Well, not in accordance with the needs and requirements of its Serb community, which by now was in a deep collective shock facing great dilemmas, after having lived for a whole decade in freedom and prosperity reserved only for them. The goals of Belgrade were: at least securing Serbian interests in Kosovo, through various forms of state regulation and, at most, maintaining Kosovo under Serbian sovereignty. Otherwise, the Serbian policy of recent decades has been known in at least two aspects: that of force, as the main policy tool, and for probability in it s center. Therefore, also in relation to Kosovo, it hoped and worked for providing physical, but also political and economic safety to the Serb element in Kosovo in order to find a political solution from "solid" grounds. The Serb community was also encouraged by Belgrade to participate in local political processes under the international organization and the administration, including the first elections after the war in Kosovo, on both a national and municipal level. The legal and political bas is of international mission in Kosovo, as well as autonomous policies of particular countries (Russia, Greece, Romania, Spain, etc.), which were part of the civil-military mission, encouraged, and even "helped in continuance of functioning and further consolidation of parallel structures in Serb-dominated areas.". While Serb structures of public services of education, health care, social security, geodesy and cadastre services could function even under international administration, as they were not considered illegal in relation to Resolution 1244, those of the public safety and state were expressly forbidden by both the Resolution and the Military Technical Agreement of Kumanovo. For more, international military authorities were responsible to oblige their departure from the territory of Kosovo. Therefore, the political and legal source of Serbian hope for the eventual return of factual power over Kosovo was exactly in the abovementioned documents, but also in the actual behavior of the international civil mission, which coexisted with illegal structures and, in certain cases, even co-governing with them thus legitimizing the structures necessary for preserving peace and stability at all costs. The guiding principles of the Contact Group of October 2005 on resolving the status of Kosovo is considered to have ended the Serb confidence for the return of their power in Kosovo. Thus, Item 6 of the Principles expressly prohibits the return to the preMarch situation of 1999, disallows changing of borders, and accepts no union of Kos ovo with any other country or any part of any other state, as well as expresses the commitment of the Contact Group to respect the territorial integrity and internal stability of regional neighbors. It is precisely these attitudes that made the official policy of Belgrade to start preparing for alternative resolution of a political and territorial autonomy for Serbs in northern Kosovo, and enhanced self-majority Serb municipalities. Therefore, the concept of such a policy still supports the very exis tence and functioning of parallel structures, which could be legitimized in resolving the political status of Kosovo, according to the Serbian plan. Belgrade had already tried such a policy earlier in Bosnia by creating the Republika Srpska. Finally, the Comprehensive Proposal for the Kosovo Status Settlement of President Ahtisaari of 26th of March 2007 internationally legitimized Kosovo's supervised independence and this continued the process of strengthening the Serb alternative policy of partition or sec ession of a part of the territory of Kosovo, especially encouraged by the Russian stance at the UN. This eventually made Serbia to continue to support all the illegal structures throughout Kosovo with logistics and finance, but also with staff. According to the current Defense Minister of Serbia, "The Serbian government in the past 13 years has spent 5-6 billion Euros for the Serbs in Kosovo", spent on financing of health, education, and illegal alternative security.

\section{Defining Parallel Structures}

The phenomenon of parallel structures or "a state within a state" is not new. The occurrence of the creation and operation of parallel institutions opposite institutions representing popular sovereignty is a socio-political phenomenon that accompanies transition societies. Such are considered societies emerging from colonization and those emerging from the process of revolutionary and evolutionary transformations of the communist system. The case studies show that parallel structures are primarily the result of polarization and socio-political divisions on ethnicity, religious, economic, and ideological basis. While the reasons for the creation and goals of parallel structures are relatively well studied and recognized, their definition has not yet been determined and dilemmas continue as to which of themcan 
be called as such and hence be treated accordingly by the internal law of the states in the framework of which they appear, but also by international law and international relations. According to Kenneth Martin, there are seven characteristics, which, either together or several at once, discern parallel structures on the basis of which they can be defined as such. First, they are illegal structures in relation to the state structures and as such they are not recognized by the state power as legitimate political authorities. Secondly, they basically are not recognized by other states as sovereign entities of international law and cannot enter into normal international relations. Exceptionally, they can be recognized by some state, although recognition would imply a violation of the UN Charter.

Thirdly, during most of their existence they are in peaceful coexistence with the power of the state within whose territory they function. Of course, with exception, occas ional tensions occur and violence of armed conflict between such structures and legal and legitimate structures. Fourth, the state in the framework of which appear parallel structures should not be a failed or collapsed state at the time of their emergence. Fifth, parallel structures are organized on the occasion of deep social divisions on ethnic grounds, but also on other grounds. Sixth, parallel structures should be deferred to the pressure created within the state. They cannot be de facto puppets of another sovereign state, created to occupy part of the disputed territory of the state within which they exist. These structures may as well have support from neighboring countries, or even can be created directly by them, but should be essentially independent in relation to other states, as well as in relation to the state in whose territory they are.

Seventh, therefore, these structures must eventually have a significant degree of the characteristics of state structures, rather resembling governing bodies than social groups. These organs control the territory, have the legitimacy of the community and provide state services from education to defense and security. Features here may find dozens of answers from the history of internal conflicts, caused by statutory changes to different states, but we will mention only a few of them for the purpose of comparis on with the possible elements of the definition, but also with illegal Serb structures in Kosovo. Thus, cases such as that of the Moldovan province of Trans dniester, South Ossetia, Abkhazia, Nagorno Karabakh, or even northern Tamil province of Sri Lanka, represent typical cases of "states within a state", i.e. of parallel structures according to the characteristics described here. They are illegal in relation to legitimate state structures. They are not internationally recognized, except by some states (Russia, Venezuela) and mutual recognition between them. Also, they are supported by Russia, but not formally legally administered, while the residents of the territories in which there are parallel structures perform basic state functions, including police and military control of the territory which they provide and the population they govern, even with legitimacy, however fragile and doubtful, verified through the electoral process and own sources of revenues. So, these structures, by definition, can be called parallel structures and, moreover, can be treated as a "state within a state" or de facto states. In comparis on with these structures, Serb structures in Kosovo, both theoretically or by popularpractices as mentioned in the above, cannot be called parallel structures and therefore cannot be treated as such. Their treatment as parallel structures not only contradicts the theoretical definitions, but it would carry big consequences for the exercise of full sovereignty of the state government of the Republic of Kosovo, and increase the likelihood for "a failed state or weak state," respectively it would delay the completion of the process of finalizing the independence. Moreover, it would set a bad precedent in international relations and international law, but also a danger to national security of many countries that have prerequisites for the appearance of this phenomenon.

\section{Serb Illegal Structures In Kosovo}

The withdrawal forced under NATO intervention of Serb-Yugoslav mechanisms of power from Kosovo in June 1999 marks the end of the war and at the same time the beginning of a new process of peace building. Despite the massive military and police withdrawal, members of the Serbian structures of security continued to reside in predominantly Serb enclaves, most of which began to reorganize, to defend the policy of S. Milosevic, whose regime continued to support the Serb strong line on staying in Kosovo by all means. "Belgrade considered Mitrovica as a place in which to make their last resistance against Albanian infringement encouraging Serbs in the enclaves throughout Kosovo by providing financial assistance, food and equipment." In Resolution 1244, the UN International Administration 
(UNMIK) was the only legal authority of the government and any other structure had to undergo it. While various organizations of Albanians, claiming legitimacy to head the joint process with the internationals in building postwar Kosovo government institutions, the Serbian government succeeded acting with urgency and in an illegitimate way to reorganize its administration, public services, and public safety and intelligent structures. So it comes to the Serbian state power structures that were forcefully installed after the abolition of Kosovo's autonomy in every municipality, which were functioning for nearly a decade and now that same system was re-organized only in those municipalities where Serbs were concentrated, or in the Serb majority municipalities respectively. While most of these structures have already been removed, or have been replaced with legitimate legal structure, and, as a result of the decentralization process and the creation of new municipalities in predominantly Serb enclaves, they continue to exist and function in the three northern municipalities of Kosovo.

\section{Illegal Courts}

Establishment and administration of the courts was UNMIK's mandate and mission. Faced with the lack of experience in other missions, in which the mandates were different from the full executive character of the mission in Kosovo, and because of difficulties linked to both technical and legal infrastructure, the International administration failed until 2003 to create and administer a judicial system in Kosovo. Therefore, the remaining Serbian justice system, in various forms and with reduced staff, continued to work and decide according to civil suit, but including also crimin al cases. According to the research of the OSCE Mission in Kosovo, Serbian illegal municipal and district courts, from June 1999 until January 2003, have solved or otherwise helped solve 5,300 cas es. Courts dealing with cases of different municipalities in Kosovo are located mainly in Serbia, with the exception of those in the north of Kosovo, which just as well as other courts, are part of the Serbian justice system. Thus, in Niš there is a court and prosecutor prosecutes and adjudicates cases of Prishtina. Court pretending to belong to Gjilan is located in Vranje, and the courts for the region of Prizren and Peja are located in Leskovac, etc. In the four northern municipalities of Kosovo, courts operate unhindered by UNMIK earlier, and EULEX now respectively. Indeed, the UN International Administration has made some efforts to extinguish these illegal structures, through the project for the integration of Serb judges and prosecutors of those courts in Kosovo justice system administered by UNMIK. In July 2002, UNMIK failed to sign a joint statement with the Serbian authorities, which obligated Serbian authorities to help the process of integration of Serb judges and prosecutors of judicial illegal structures into UNMIK-s Kosovo system of justice. As a result of this agreement, in Zubin Potok, Leposavic, and North Mitrovica, Serbs started to become part of the courts organized and supported by UNMIK, and also by interim local government bodies. In other parts of Kosovo, individual judges and prosecutors were in tegrated in the Kosovo justice system. Nevertheless, in Serbia courts claiming jurisdiction in Kosovo still persist.

\section{Illegal structures of security}

The activity of Serbian security structures in Kosovo has been ongoing since 1999 in different forms and ways. Republic of Serbia, although obliged to withdraw every member of any security organization out of Kosovo, has maintained throughout Kosovo its presence through intelligence structures and adminis trative and police structures. These structures have continued to provide internal services related to identification documents, travel documents, driving licenses, etc., and have continued to serve the Serbian intelligentsia, whether military or civilian and police. In this way and with the same or similar missions, officials of MUP continue to still function and be under the administration of Coordination Directorate for Kosovo, which is part of the organizational chart of the Ministry of Interior of the Republic of Serbia. The Directorate is the highest level of the organization, which "coordinates the work of police departments and police stations, exercising police tasks as determined by law and otherinternal functions, in accordance with the special conditions and circumstances in Kosovo..." According to reports by MUP of Serbia, in Kosovo there are also 7 directorates as well as police stations realizing their mission in accordance with the specific conditions and circumstances authorized to also engage and deal with protection and rescue activities. However, the structure of this organization, even formally, stands on a shaky position to be equated with other departments within the organizational 
structure of the MUP of Serbia, and as such it is an organization coordinating administrative activities rather than operating activities. So, it continues to be a reflection of an official Serbian policy, which is politically and legally still considering Kosovo as part of Serbia. The situation in northern Kosovo is different, where the "activity of Serbian security structures has been continual since 1999." In these municipalities, especially in the northern part of Mitrovica, the following have continued to function in different operating ways: public safety structures, civil and military intelligence services (BIA and VBA), and structure of Civil Protection. According to various reports of the International Cris is Group and the annual reports of the OSCE mission to Kosovo, the most active and violent illegal structure, immediately after the war, was the structure of the "Bridge Guards" supported by Belgrade. The main tasks of this structure were: to prevent the passage of the Albanians to northern Mitrovica, to gather information on KFOR and CIVPOL, and gather information about the Albanians who live in north Mitrovica. So these structures were an operational part of the Serbian state structures, which exert their activity under the guise of popular and spontaneous arrangements on behalf of protection frompossible Albanian retaliation. As such, and with this pretext, they were well tolerated by the international sector of security and have functioned as a structured organization at the beginning of the year 2004-2005, while in various forms and with different members continue to conduct information collection, as well as surveillance, alert notification for civil protection sector. ... This structure has continuously cooperated with the Serbian MUP officials from Serbia and the former pre-war Serb police in Kosovo, who were paid by the Serbian state budget. According to the data of the Ministry of Interior of Kosovo it is estimated that in the northern municipalities operate about 200 Serbian MUP officials, who in "accordance with the special conditions and circumstances" are trying to implement security policies of the government of Serbia. A number of them are also operating within the Kosovo Police, integrated in the years 2004-2006 and for a time were paid by both Serbia and Kosovo. MUP of Serbia organized a special structure for North Mitrovica directorate headed by a chief and deputy chief, overseeing four commanders of four virtual police stations. Territorial Defense has also been well structured, consisting mainly of former Yugoslav and Serbian army officers and firefighters. These structures too are administered by the Republic of Serbia and their main role is to alarm and mobilize the population to prevent any real exercise of state sovereignty of the Republic of Kosovo, and also to thwart a full realization of KFOR and EULEX missions. The existence of these illegal structures are supported and justified by both Belgrade's official policy, as well as local political leaders of the Serbian community in the north, on the basis of the perception of uncertainty and mistrust on international and local legal structures of security. They continue to even contribute and deepen these perceptions, with the aim of legalizing the status of these structures and realizing special status with judicial and police autonomy for northern Kosovo.

\section{Illegal Structures of Public Services}

Using the same practice as with the security structures, Serbia, immediately after the war, came to reorganize some of the key public services of education and health care for the citizens of the Serb community, mainly in Serbian majority areas. According to an International Cris is Group report of 2011, in Kosovo still continues to operate illegally an education system directly funded and administered by the Ministry of Education and Science of the Serbian government, with a high budget cost. Thus, in northern Kosovo alone, for 21 primary schools and 9 secondary schools about 45 million Euros are spent annually. They are even managed directly by the office of the Serbian education located in the northern part of Mitrovica. The illegal system of education still continues to operate outside the legal education system of the Republic of Kosovo. It is to be found all over Kosovo and is structured throughout the regions of Kosovo, the existence and operation of which, according to extensive interpretations, is encouraged even by the President Ahtisaari's Comprehensive Plan for the Kosovo Status Settlement within the package of laws within which is adopted the Law on Education of 2008, which allows education according to Serbian curricula. Under this plan schools that offer instruction in Serbian can implement curricula or textbooks compiled by the Ministry of the Republic of Serbia with the notification of the Ministry of Education of Kosovo, and if the latter disagrees then it is required to form a competent committee to finally decide. The Committee consists of three deputies of the Assembly of Kosovo holding seats reserved or guaranteed for the Serb community, three representatives of the Ministry of Education of Kosovo and a representative of International Civilian Office. Moreover, 
the illegal system of education is part of the education system of the Republic of Serbia in structural, organizational, and financial aspects. Segments of this system are part of the organizational structure of the Ministry of the Republic of Serbia divided into two directorates of education: that of Ranilug, covering the network of Anamorava schools, and the Department of Education for Mitrovica, covering the illegal network of district education of Peja, Prizren, Mitrovica, and Kosovo Plain. So this too is a case of remaining and reforming according to the "conditions and circumstances" of the education system of the Republic of Serbia. Like the illegal system of education, the health system too continues to operate unhindered throughout Kosovo. Mainly primary medicine functions, while the secondary is concentrated in the northern part of Mitrovica, with some secondary services in other parts of Kosovo. There are three main centers of Kosovo, through which hospital centers, health centers and medical clinics are managed. Thus, in the Prishtina region, there is a hospital with several specialized branches, spread across predominantly Serb populated settlements, as well as two health centers and 15 clinics. In the Gjilan region there are 39 health institutions, operating in Gjilan, Kamenica and Shterpce. In the Prizren region there are also some Health Centers in Hoqe e Madhe and Srecke. In the Peja region several clinics in private homes of members of the Serbian community have been identified, as linked to illegal health system of the Republic of Serbia. Illegal Serb Health Care in Kosovo is particularly well organized in its northern municipalities. In the northern part is a hospital center with around 1600 employees and with an annual budget of 16.5 million Euros. Also providing primary medical services are 5 health centers and 16 medical clinics. Therefore, completely in line with models of other illegal systems, this system continues to exist and work wherever Serbs are in a majority, on the grounds that members of the Serb community still do not have enough freedom and security, especially on the grounds that these members do not have faith in the Albanian medical staff.

\section{Other illegal structures}

In addition to the public services, in the territory of Kosovo, mainly in the north, continue to operate Serbian adminis trative structures that is sue adminis trative acts on the property such as: possession title deeds, alienation of property, building permits, etc. on the basis of the legis lation of Serbia, even on the basis of its Spatial Planning. They continue to act organized in directorates of urbanism in Leposavic, Zubin Potok, and Zvecan, while the personnel of these adminis trative structures to other municipalities of Kosovo continue to operate, though not regularly, in Krusevac, Leskovac, and Nis. Therefore, these structures are remnants of structures of Serbia, which are fully overhauled and operate according to the model of the organization and functioning of other illegal flexible structures and are under the administration of the governance structures of the Republic of Serbia.

\section{Conclusions}

This comparative study of some of the typical parallel structures that exist in some fragile states and weak states, especially in Asia, on the one hand, and on the theoretical review of concepts of parallel governance, on the other hand, a conclusion may be drawn that all the Serbian structures in Kosovo, organized outside the common system of local and international governance, are unconstitutional structures, and therefore illegal, rather than parallel structures. Moreover, they are remnants of the Serb forced system of governance of Kosovo Serb, which, reorganized, continue to be administered and funded directly by the Republic of Serbia, while certain segments are supported by criminal structures as well. Their treatment as parallel structures by the international administration in Kosovo (UNMIK) has been a crucial mistake, consequences of which were felt mostly in the process of integration, development, and democratization of a part of the Serbian community in Kosovo's northern municipalities. In addition, the connection of these illegal structures with criminal structures has led to the latter, under the umbrella of the first, continuing to seriously impede the exercise of state power, the legal system, and the development of democracy in that part of Kosovo. Structures like these, except legality, also lack legitimacy, for as long as the representatives of the Serbian community in Kosovo are by now part of the three branches of government in Kosovo. Therefore, the separation and clear definition of these structures and their respective state treatment (political, diplomatic, and military - 
police) is a long entry into the process of implementation of the Comprehensive Plan of President Ahtisaari, as the only plan which provides integration, development, and democratization of that part of Kosovo. While the dismantling of illegal structures may be treated by means of the international political and diplomatic pressure on Belgrade to terminate their funding, a state organized force with an international support is the only answer to criminal structures.

\section{References}

1. Gezim Visoka \& Grace Bolton (2011): The Complex Nature and Implications of International Engagement after Kosovo's Independence, Civil Wars, Vol.13

2. Jock Covey: "Making A Viable Peace-Moderating Political Conflict", in "THE QUEST FOR VIABLE PEACE - INTERNATIONAL INTERVENTION AND STRATEGIES FOR CONFLICT TRANSFORMATION", EDITED BY JOCK COVEY, MICHEL J.DZIEDZIC AND LEONARD R. HAWLEY, United States Institute of Peace, Washington DC, 2005

3. North Kosovo: Dual Sovereignty in Practice, Crisis Group Report N. 211, 14 March 2011

4. Tozun Bahcheli, Barry Bartmann, Henry Felix Srebrnik, De facto states: the quest of sovereignty, Rutledge, 2004

5. Doc. Dr. Slavisa Orlovic, Kosovo i Mtohija-izmedzu obecane nezavisnosti i fakticke podele

6. Claire McLaughlin: "TOPIC GUIDE ON FRAGILE STATES”, International Development Department, University of Birmingham, August, 2009

7. Organization for Security and Co-operation in Europe - Mission in Kosovo/ Department of Human Rights, Decentralization and Communities: "PARALLEL STRUCTURES IN KOSOVO 20062007", Prishtina

8. Comprehensive Proposal on Status Settlement of Kosovo, March 26, 2007

9. Report on Parallel Institutions in the North of Kosovo, Office of Coordinator for Strategy in North of Kosovo, May 2011

10. Информатор о раду Министарства просвете и науке Републике Србије, Београд, Април 2012

11. Informator o radu Ministarstva Unutrasnjih Poslova Republike Serbije, Beograd, 2012

12. UNSC Resolution no.S/RES/1244 (1999)

13. Kumanovo Technical Military Accords (09.06.1999)

14. The Rambouillet Agreement (18.03.1999) 